\title{
How was Mulka's Cave, an Aboriginal rock art site near Hyden, in south- central Western Australia, used by the people who decorated its walls, when the present entrance was much smaller?
}

\author{
R. Esmée Webb ${ }^{1}$ and Alana M. Rossi ${ }^{2}$ \\ School of Natural Sciences, Edith Cowan University, Joondalup, Western Australia 6027, Australia. \\ Email: e.webbecueduau \\ Kurongkurl Katitjin, Edith Cowan University, Mount Lawley, Western Australia 6050, Australia. \\ Email: alana 31 (th hotmail.com
}

\begin{abstract}
Analysis of old photographs and survey data shows that nearly one metre of the sediment in Mulka's Cave, a protusely decorated Aboriginal rock art site in south-western Australia, has disappeared in the last 50 years. This evidence for erosion prompted us to reassess the results of previous research at the site. Our reconstruction of the floor level in 1950 affects light levels within the cave and the visibility of the artwork, causing us to reconsider how the cave was used when the artwork was made and to suggest that the present entrance may not then have been in use. Investigation of the deposits immediately outside the cave suggests, furthermore, that that area may not have been a major focus of camping. Rather, camping occurred near a series of gnammas $500 \mathrm{~m}$ north of the cave.
\end{abstract}

Keywords: sediment erosion, cave morphology, rock art, south-western Australia.

\section{INTRODUCTION}

Mulka's Cave, site 5842 on the Register of Aboriginal Sites maintained by the Western Australian Department of Indigenous Affairs (DIA), is large granite boulder that began to weather into its present hollowed out shape in the late Mesozoic. The boulder is part of The Humps (Twidale and Bourke 2004), an impressive dome of Late Precambrian granite situated $15 \mathrm{~km}$ north of Wave Rock, a heavily-promoted natural granite weathering feature located $3 \mathrm{~km}$ north of Hyden (Figure 1). Hyden is $300 \mathrm{~km}$ southeast of Perth on the eastern edge of the Wheatbelt in south-central Western Australia

Mulka's Cave contains 452 pictograms (painted motifs), a very high number by comparison with the other decorated rockshelters known in the Wheatbelt, which mostly house fewer than 100 motifs (Webb and Gunn 2004). Those in Mulka's Cave comprise ' 275 handstencils, 40 sprayed areas, 23 handprints, 23 paintings, three drawings and [an] object stencil [in] a wide range of colours (Gunn 2006a: 19): brown, orange, yellow and cream, as well as white and the many shades of red that are ubiquitous in Australian rock art. Due to its proximity to Hyden, Mulka's Cave is now visited by most of the approximately 80,000 tourists who visit Wave Rock each year; particularly those on commercial tours. This level of visitation, 200 people a day on average, is extremely high for a spatially restricted site whose rock art Gunn (2006a) considered fairly 'ordinary', because handstencils predominate; as they do throughout south-western Australia (Davidson 1952).

That the environs of Mulka's Cave were deteriorating due to over-visitation has been known for 20 years (Rodda 1989), but the extent of the damage was not, perhaps, fully appreciated until recently. We first visited the cave in April 2004, when Gunn (2006a) recorded the artwork in detail. We returned in April-May 2006, to monitor installation of an elevated walkway with a viewing platform and new signage (Figure 2); part of site management improvements undertaken by tourist organisations in Hyden, with the support of the Mulka's Cave Aboriginal Steering Committee and the consent of the Minister of Indigenous Affairs. When we compared the photographs of the cave mouth we took on both occasions, the shape of the entrance had visibly changed; prompting us to examine other pictures of the site that could be dated (Day 1951; Serventy 1952; Randolph 1973; Bowdler et al. 1989). Figure 3 is the result of that research. It shows that by 1988, when Bowdler et al. (1989) test excavated the floor deposits just inside the dripline, about $0.5 \mathrm{~m}$ of sediment had been eroded from the 1950 level, when the entrance was $<1 \mathrm{~m}$ high. By 2004, another $0.5 \mathrm{~m}$ of deposit had 


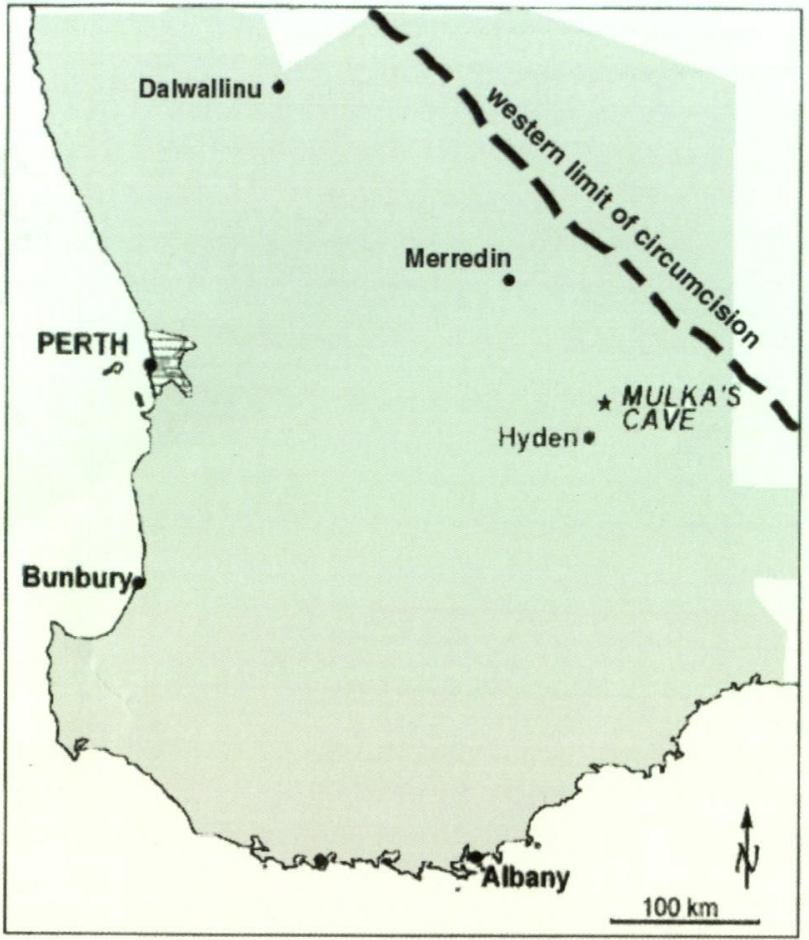

Figure 1 Location of Mulka's Cave relative to Tindale's (1974) circumcision line (the area covered by the Noongar native title claim is shaded).

been lost, explaining why all trace of the test pit has disappeared. That erosion was accelerating is shown by the amount of sediment lost between 2004 and 2006. Had the walkway not been installed, erosion would have continued unabated because the deposits outside the cave were probed to a depth of one metre without reaching bedrock. We believe this erosion is due to the number of tourists who now visit the site (Rossi and Webb, 2008, in press). For example, in May 2006, five or six coach- loads of tourists, plus independent travellers, visited the cave on some days; about 150-200 people. Visitation is much higher in spring, when the wildflowers are blooming; lower in the height of summer.

Although Mulka's Cave is large: 15 m east-west, 9 $\mathrm{m}$ north-south and $2.5 \mathrm{~m}$ high; there are not many places where visitors can stand comfortably to view the artwork. The cave is filled with boulders, some very large, that appear to have fallen from the roof or rolled into the cave from the rock tumble upslope on The Humps, while the floor at the base of the rock pile now measures only $2 \times 7 \mathrm{~m}$. Commercial tour groups often comprise 30 people. When they enter the cave, two of these people are crowded into each square metre of floor space, unless some climb onto the boulder pile, a practice that is now discouraged, easing the congestion below. Because the cave entrance is quite constricted, the people in these tour groups used to cluster outside the cave before and after viewing the artwork, scuffing up the devegetated ground surface. Now they are confined to the walkway and do not impact the ground. The cave floor has been covered with rubber matting, the deposits between the end of the walkway and the matting have been consolidated and the degraded external deposits planted with Allocasuarina huegeliana (Sheoak) seedlings, most of which were flourishing when we visited the site in late May 2007. The new signage explains the significance of the artwork, tells Mulka's story and discusses what little is known about the archaeology and early history of the Aboriginal people of the area around Hyden.

Mulka was a fearsome Dreaming Being of enormous size who lived in the cave. The stencils are said to be of his hands; partly because many are

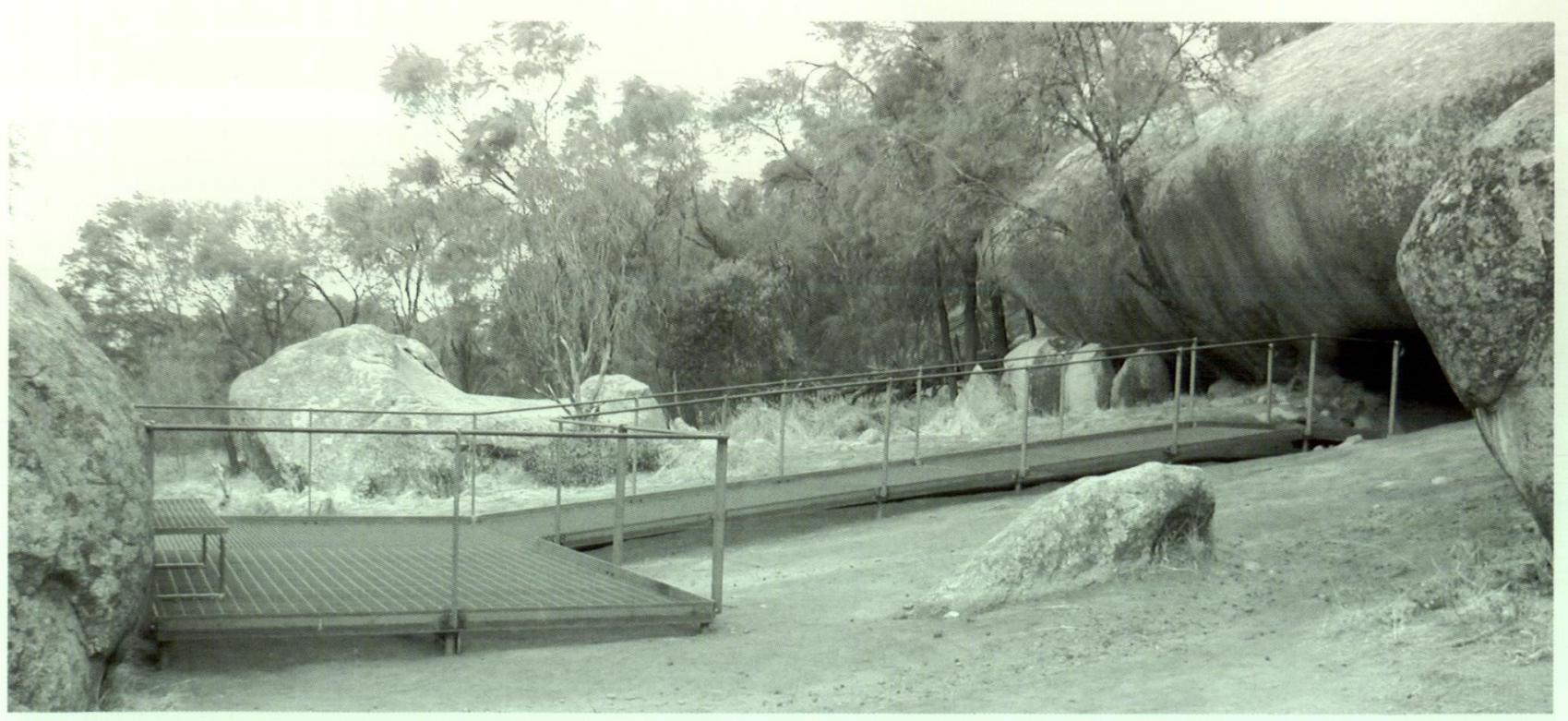

Figure 2 The raised walkway installed outside Mulka's Cave in May 2006. The viewing platform now carries several informative signs. 


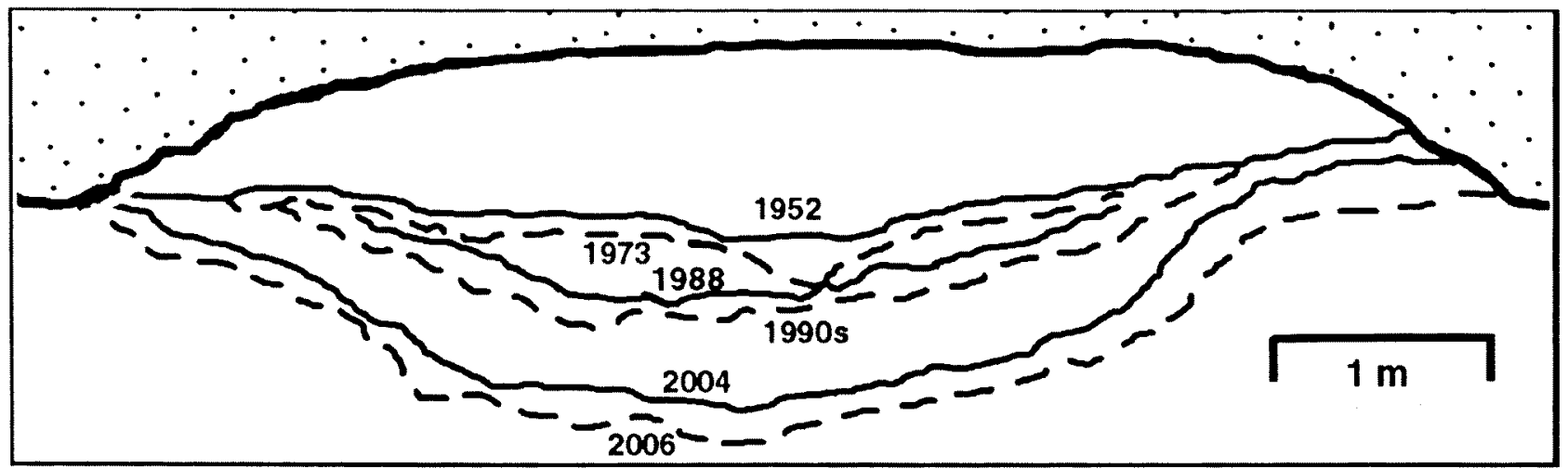

Figure 3 Reconstruction of the ground level at the mouth of Mulka's Cave between 1952 and 2006, based on Day (1951), Serventy (1952), Randolph (1973), Bowdler et al. (1989) and photographs taken in 2004 and 2006 by AMR.

high up on the ceiling. He was the illegitimate result of a 'wrong' relationship. He was born with crossed eyes and took to eating children because he could not hunt effectively. When his mother scolded him, he killed her and fled. His tribe chased him to Dumbleyung, $150 \mathrm{~km}$ south-west of Hyden, and killed him. The members of the Mulka's Cave Aboriginal Steering Committee who inspected the walkway told us they knew Aboriginal people who were too frightened of Mulka to go into the cave. They themselves would not go in after dark. Indeed, when with us at the site, they did not enter the cave at all; although they had no objection to us or tourists going in.

Bowdler et al. (1989) doubted the authenticity of the Mulka story, because it was first reported by a local farmer in the 1970s. On the other hand, Gunn (2006a: 21) said he had 'recorded similar myths in Central and Northern Australia, and considered [the Mulka story] to be quite typical of local (non- travelling) myths'. Similar stories were also recorded by Meggitt (1962: 261-262) from the Warlpiri, a Western Desert language group with cultural links to the people occupying the country to the east of Mulka's Cave. Mulka's story was also recounted at length on information leaflets about the site produced by DIA in the 1980s. There is little chance of authenticating the story now, however, because much traditional knowledge was lost when Aboriginal culture collapsed within one or two generations of British arrival in the south-west in the early 1800s (Green 1981).

\section{WHICH ENTRANCE TO MULKA'S CAVE WAS IN USE WHEN THE ARTWORK WAS MADE?}

Our realisation that the ground level inside the cave used to be much higher (Figure 4), caused us to wonder whether the present entrance to Mulka's Cave was the main entrance when the artwork was

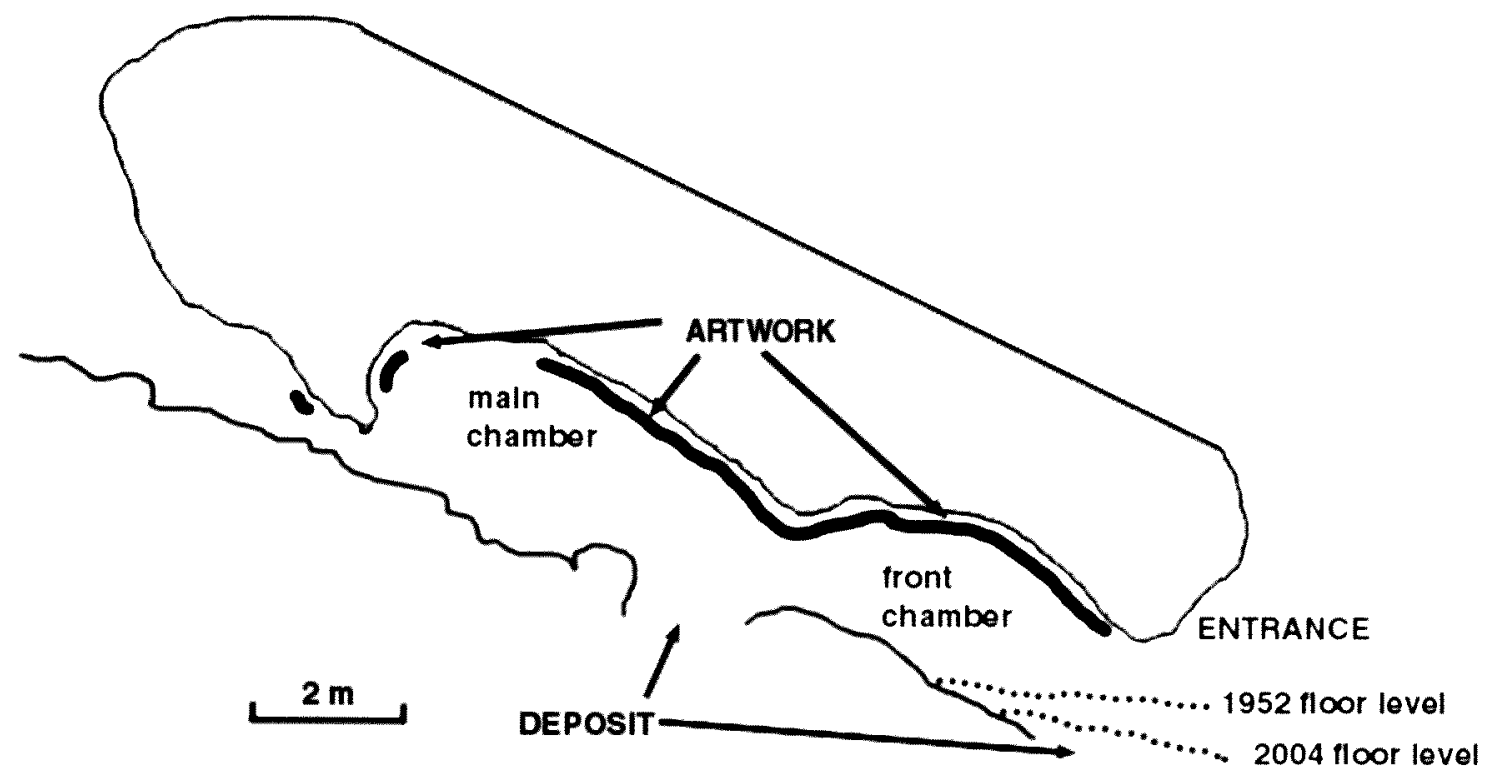

Figure 4 Reconstruction of the ground level within Mulka's Cave in 1952 compared with the level in 2004 , adapted by AMR from Gunn (2006a: figure 4). 


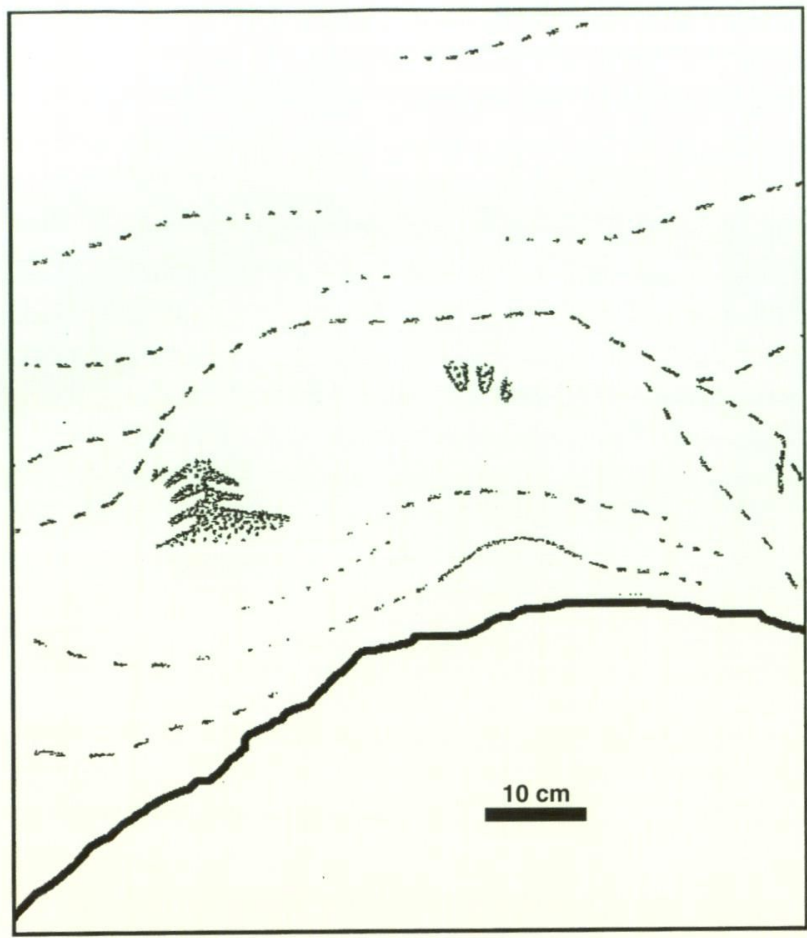

Figure 5 Handstencils outside what is now the rear entrance to Mulka's Cave, but may have been the main entrance when the artwork was made (Gunn 2004: figure 16). made. Several non-Aboriginal local residents visited the site while the walkway was being installed. They told us that when they first visited the cave as children, 40-50 years ago, they had to crawl in. In other words, the ground was probably at the 1950s' level. What Gunn (2006a) understandably described as the rear entrance, because it faces The Humps and is filled with rock tumble, we now think may have been the main entrance in antiquity. This entrance is easily accessed by scrambling among the boulders that surround Mulka's Cave up to a shoulder of The Humps. We think this entrance has changed little over the last 3,000-4,000 years, the period during which Gunn (2006a) thought the artwork was made, partly because the bedrock is Archaean and has been weathering in situ for millions of years, partly because many of the boulders that fill it are too large and heavy to move easily. Certainly, this entrance has not changed noticeably since it was recorded by Serventy (1952). It is still about $2 \mathrm{~m}$ wide and $1.5 \mathrm{~m}$ high. It is marked without and within with handstencils (Figure 5); whereas, if there ever were any artwork on the outer face of the lower entrance, it has disappeared. Water pours over that face when it rains (Figure 6), however; whereas the artwork

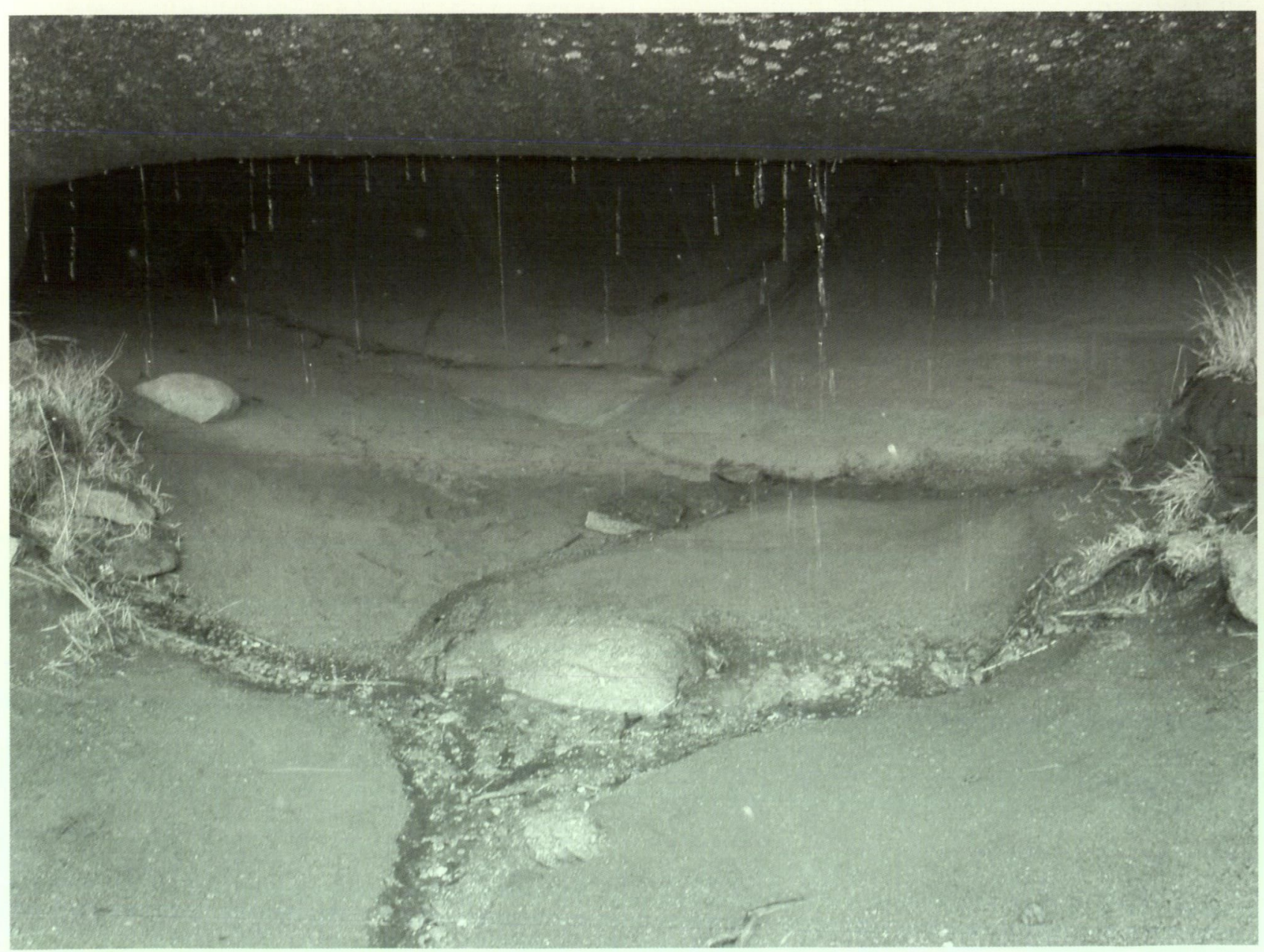

Figure 6 Rain falling over the present entrance to Mulka's Cave in June 2005. 
outside the upper entrance is protected from the weather by overhanging rock.

The handstencils outside the rear entrance to Mulka's Cave could have been intended to alert the uninformed that the boulder was decorated. We know of other rock art sites in the south-west where the decorated boulder in a cluster of boulders is marked externally, but we also know of clusters of boulders where the decorated boulder is not marked; so that suggestion needs to be tested by accumulating more data, if possible.

The inside faces of the outer walls of the lower chamber in Mulka's Cave carry not only handstencils but most of the linear paintings, which are best viewed from within the rear entrance. Whether they were placed there for that reason cannot now be ascertained; but if they were, their placement would support our suggestion that the cave was entered from the rear when the artwork was made. How many motifs were made on the inside face of the lower entrance is unknown because that area used to be badly defaced with graffiti; some of which is still visible. Its removal by members of the Department of Aboriginal Sites (Randolph 1973; Clarke 1976; Haydock and Rodda 1986), now DIA, removed the underlying artwork as well. Traces of pigment survive, but they are too fragmentary to interpret.

Sunlight rarely penetrates directly into Mulka's Cave; the entrances are too low. The local residents who visited the site in May 2006 told us that when the present entrance was smaller the cave was very dark and the artwork was difficult to see. Torches

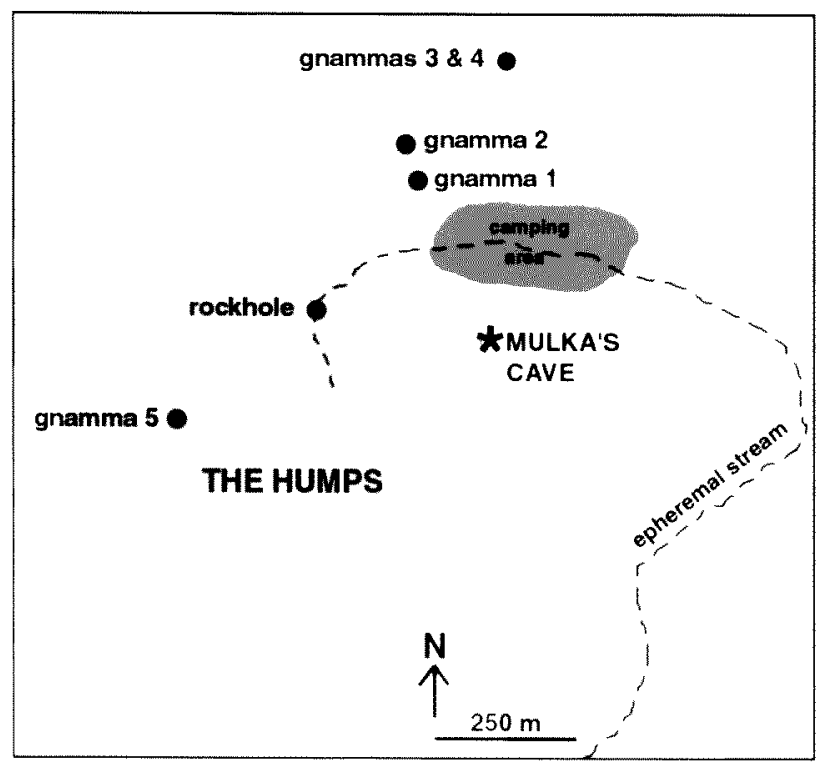

Figure 7 Plan of The Humps showing the gnammas and the area that appears to have been the focus for Aboriginal occupation, adapted by AMR from Gunn (2006a: figure 3). were essential. Even now, one needs to allow one's eyes to adjust to the low light levels before some of the motifs become visible. Most can be detected without artificial illumination, however. If our reconstruction of the cave interior in the $1950 \mathrm{~s}$ approximates conditions when the artwork was made, light levels would then have been low. In that case, the artwork in Mulka's Cave may not have been intended to be easily seen, making it very different from other art sites known in the southwest, most of which are quite open and well-lit, even those housing paintings we think probably had secret/sacred significance when they were made; although interpretation of their meaning is no longer possible due to the cultural dislocation and loss of knowledge that followed colonisation (Green 1981). Usually, handstencils are assumed to be 'public art'; interpreted as 'claims to country' (Moore 1977). The possibility that those in Mulka's Cave were not, but had ceremonial significance, is discussed below.

\section{WHERE DID PEOPLE CAMP AT MULKA'S CAVE?}

Despite being surrounded by farmland now, Mulka's Cave really lies on the western edge of the semi-arid zone. Rainfall is uncertain and for seven years in ten the amount received at Hyden fails to reach the annual average of $345 \mathrm{~mm}$ (Bureau of Meteorology data). Research in the Western Australian semi-arid zone has shown that ceremonial sites are usually located near supplies of freshwater (Gunn and Webb 2000, 2002, 2003, 2006; Webb and Gunn 2004), but free-standing potable water is scarce around Hyden. There is no active drainage and the rare lakes are hypersaline. Moreover, when rain falls it is quickly absorbed by the sandy soil, or it collects in the salinas and is undrinkable. Rainwater also collects in gnammas, however; rockholes in granite outcrops that Aboriginal people throughout Australia are known to have used because the water they hold stays fresh (Bindon 1997; Bayly 1999).

Five gnammas, two with lids, have formed within $500 \mathrm{~m}$ of Mulka's Cave (Figure 7). The two largest were recently cleaned out, allowing their full depth to be measured. There is also a large runoff-fed collection point that has developed along a bedrock fault on The Humps. In Table 1, the capacity of these water sources has been calculated as follows: $1 \mathrm{~m}^{3}=1,000 \mathrm{l}$, the volume of a cylinder is $\pi r^{2} h$, that of a hemisphere is $2 \pi r^{3} / 3$. Which formula is used affects volume estimates: a sub-cylindrical gnamma $2 \mathrm{~m}$ in diameter and $1 \mathrm{~m}$ deep holds about 3,000 l; a sub-hemispherical gnamma $2 \mathrm{~m}$ in diameter with a maximum depth of $1 \mathrm{~m}$ holds about 2,000 1. The gnammas at The Humps are all ovoid or subcylindrical, although the two largest have wide 
Table 1 Dimensions in metres and capacity in litres of the water sources identified near Mulka's Cave, revised from Gunn's (2006a: Table 15) estimates.

\begin{tabular}{lcccrr}
\hline water source & length & width & depth & capacity & Gunn (2006) \\
\hline Humps 1 top & 1.60 & 1.10 & 0.15 & 200 & - \\
Humps 1 bottom & 1.40 & 0.85 & 0.95 & 950 & 77 \\
Humps 2 top & 3.50 & 2.50 & 0.10 & 700 & 200 \\
Humps 2 bottom & 2.00 & 2.00 & 0.90 & 2,800 & 300 \\
Humps 3 & 0.45 & 0.20 & 0.30 & 25 & 3 \\
Humps 4 & 0.20 & 0.15 & 0.20 & 5 & 1 \\
Humps 5 top & 0.85 & 0.60 & 0.20 & 80 & 13 \\
Humps 5 bottom & 0.25 & 0.20 & 0.15 & 6 & 650 \\
cleft rockhole & 8.50 & 2.00 & 0.80 & 7,000 & 1,250 \\
\hline
\end{tabular}

shallow mouths that quickly narrow to deep shafts (Figure 8). For those gnammas whose width and length differed markedly, $r$ was taken to be $L+W / 4$. The cleft rockhole on The Humps tapers and deepens markedly upslope and has a V-shaped profile. Its volume was calculated as $(L W D) / 2$. These water sources all fill simultaneously whenever it rains, providing about 12,000 $\mathrm{l}$ of water in total, ten times Gunn's (2006a) estimate. The volume of water occasionally available near Mulka's Cave may explain why it was chosen for decoration and should have made The Humps a focus for Aboriginal occupation, given the dearth of potable water in the surrounding country. Finding where people camped has not proved easy, however. They do not appear to have occupied the cave, for example.

Bowdler et al. (1989) thought that most of the 208 artefacts they recovered from the $0.65 \mathrm{~m}^{3}$ of deposit they excavated from within the cave had been disturbed after deposition because they were mixed with (undescribed) 'European material'. They said that only the core, six flakes (one with secondary modification) and 24 flaked fragments found $>0.5 \mathrm{~m}$ below the surface had 'some stratigraphic integrity' (Bowdler et al. (1989: 23). These 31 artefacts came from $0.15 \mathrm{~m}^{3}$ of sediment; a very low rate of discard.

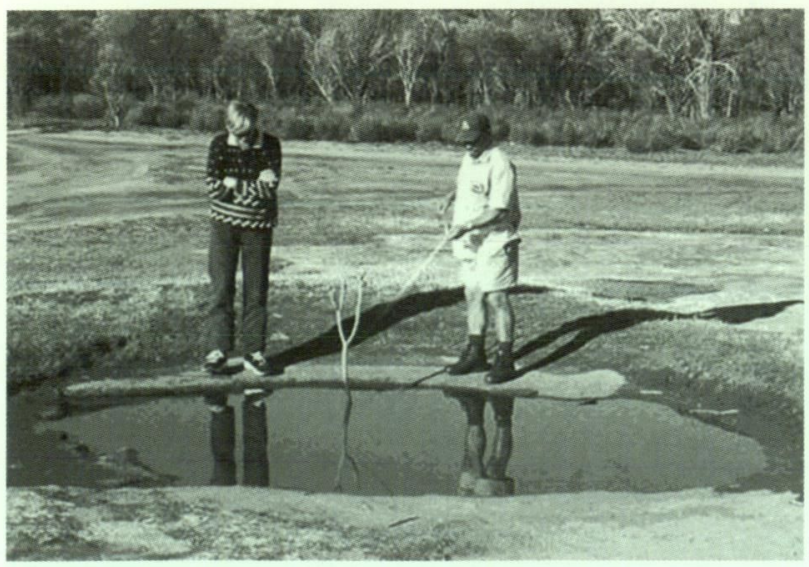

Figure 8 Gnamma 2 at The Humps (photo: R.G. Gunn 2003).
Consequently, Bowdler et al. suggested that the cave was visited infrequently. We concur. If the floor was at the 1950 level when the cave was in use, the interior would have been more cramped and much darker than it is now, and possibly quite damp.

Figure 4 shows that the flat area at the base of the rock pile inside Mulka's Cave would have been slightly larger than at present when the floor level was a metre higher, but the cave roof would have been commensurately lower. Theunissen et al. (1998) showed that ceiling height affects how people move around in caves. We think there would have been few places at the base of the rock pile in Mulka's Cave where adults could stand upright when the floor was at the 1950s' level, while there are few other places where a fire could be lit; making the cave an unlikely camping spot. There are no traces of smoke blackening on the ceiling or walls, but the cave would be dank and gloomy without a fire to give warmth and light. Consequently, we doubt whether people ever camped in Mulka's Cave, as against visiting it for ceremonies; a suggestion first made by Hallam (1975).

Gunn (2006a: 35-36) thought the area outside the present entrance was the main focus of camping activities. He noted that artefacts, predominantly quartz $(90 \%)$, were scattered over this area, which measures about $15 \mathrm{~m}$ north-south by $20 \mathrm{~m}$ eastwest. He analysed 132 pieces visible in the erosion gully shown in Figure 9, over which the walkway was later constructed. They comprised chiefly knapping debris (95\%), but included three backed flakes and a geometric microlith that Gunn assigned to the Australian Small Tool Tradition, which is conventionally dated to $<6,000 \mathrm{BP}$ (Mulvaney and Kamminga 1999: 230-256).

In April 2006, before installation of the walkway began, we collected every artefact visible on the surface of the entire area shown in Figure 9. Only one or two artefacts were found in any one square metre; many squares contained no artefacts. This is a very low rate of discard for a frequently visited 


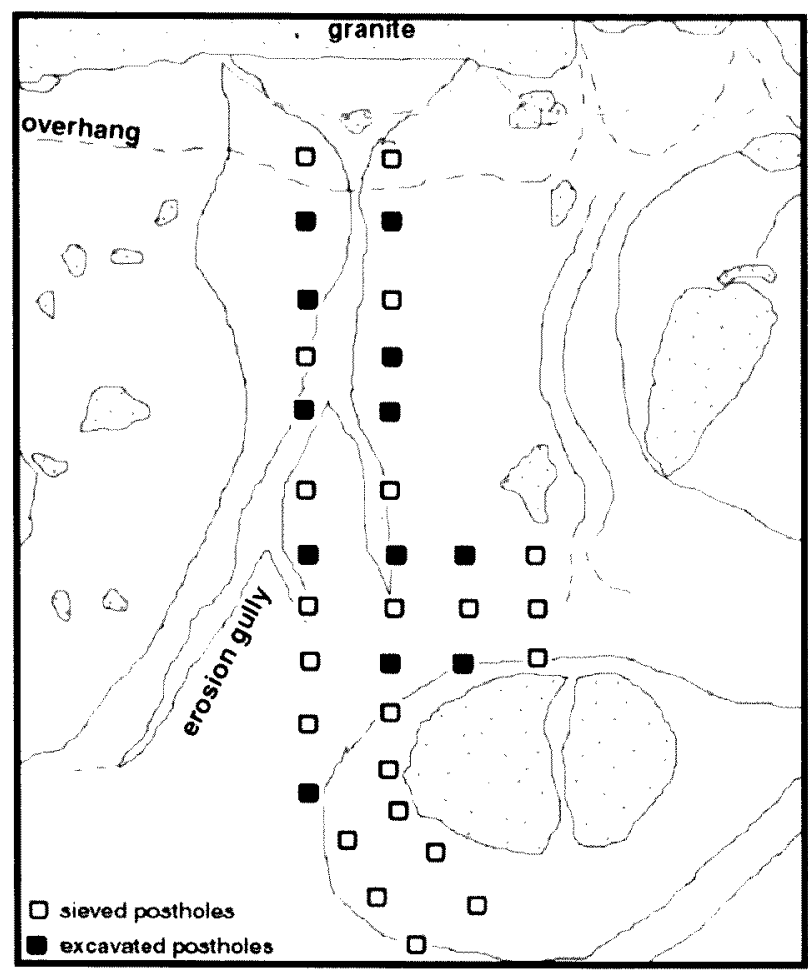

Figure 9 Position of the postholes dug to support the walkway outside Mulka's Cave.

campsite. The artefacts comprise chiefly knapping debris, but include several backed pieces and a geometric microlith made from clear quartz. These artefact types are conventionally assigned to the Australian Small Tool Tradition. Several pieces of old bottle glass had also been flaked. One has a maker's stamp that may be datable. They suggest that Aboriginal people were still visiting Mulka's Cave after the British began exploring the surrounding region in the mid-late nineteenth century. Bowdler et al. (1989: 5-6) said sandalwood cutters were active around The Humps in 1847. John Septimus Roe, Western Australia's first Surveyor General, passed nearby in 1848 (Roe 1852) and, in April-June 1893, following the discovery of gold at Kalgoorlie, John Holland, a kangaroo shooter, cut a track from Broomehill to Coolgardie that passed near The Humps (Holland 1936). Michael Cronin, a resident of Katanning, explored the region at about the same time (Bignell 1981: 122). His son Donald's name is carved on the large boulder in front of which Bowdler et al. (1989) dug their testpit; while the words 'M. Cronin 1894' were removed from the ceiling of Mulka's Cave by Randolph (1973), along with other graffiti. The Cronins appear to have been the first nonAboriginal people to leave their mark in Mulka's Cave. Most of the old flaked glass need not necessarily have been worked by Aboriginal people, of course, although cultural heritage consultants regularly find pieces of flaked bottle glass in scatters of stone artefacts assumed to have been made by Aboriginal people. The presence of worked glass at Mulka's Cave is, therefore, unsurprising.

Installation of the support posts for the walkway permitted us to examine the subsurface deposits outside Mulka's Cave. Thirty-four holes each 300 $\mathrm{mm}$ square and $650 \mathrm{~mm}$ deep had to be dug. Twelve of these postholes were carefully excavated in $50 \mathrm{~mm}$ spits (Figure 9), artefacts being recorded in situ whenever possible (Webb 2006). Those identified to date include multi-platform cores, whole and broken flakes and flaked fragments, but few secondarily modified pieces. They are being studied by AMR as part of her MA research. The excavated sediment was passed through $6 \mathrm{~mm}$ and $3 \mathrm{~mm}$ sieves; as was that shovelled from the other postholes. All the material coarser than $3 \mathrm{~mm}$ was retained for analysis. Fewer than 10 artefacts, predominantly in quartz of medium quality, were recovered from any one posthole; mostly in the top $300 \mathrm{~mm}$ of the deposit in the postholes nearest the cave. The postholes farthest from the cave yielded almost no artefacts. We believe that these artefacts may originally have been discarded in the cave and transported outside by trampling and solifluction (Rossi and Webb, 2008, in press). We estimate that about $10-15 \mathrm{~m}^{3}$ of deposit has disappeared from within the cave in the last 50 years. If that sediment were spread over the slope outside the cave it would form a layer about $300 \mathrm{~mm}$ thick. More sediment would, of course, be deposited near the cave mouth, less farther away; explaining the pattern of artefact discard we found in this area and emphasising the sparsity of the assemblage. For all these reasons, we do not think Mulka's Cave itself or the area immediately outside were camping foci. Rather, camping occurred in the area shown in Figure 7; a belt of trees fringing an ephemeral creek halfway between the cave and the two largest gnammas.

Members of the Mulka's Cave Aboriginal Steering Committee told Robert Reynolds (pers, comm. 2006), the Senior Heritage Officer with DIA who coordinated the walkway project, that when they came to The Humps as children, 30-40 years ago, they camped in this area. It was recently investigated. An extensive, moderately dense, artefact scatter was found into which a testpit 500 $\mathrm{mm}$ square was dug in May 2007. Artefacts were found to a depth of $-300 \mathrm{~mm}$, suggesting that the area had been occupied over a considerable period. The age of this occupation has yet to be established, nor have the artefacts been fully analysed, but we think that when people visited Mulka's Cave they mostly camped here because the number of artefacts recovered from individual spits in this testpit exceeded those found in the walkway postholes by an order of magnitude (about 40 artefacts from $0.0125 \mathrm{~m}^{3}$ ). 


\section{WAS MULKA'S CAVE PRINCIPALLY A CEREMONIAL SITE?}

Due to the cultural dislocation that followed colonisation, nothing is known about how Aboriginal people used Mulka's Cave before the British settled south-western Australia. Gunn (2006a) thought, however, that the large geometric paintings in the cave were almost certainly made by senior men and probably refer to the Dreaming tracks of totemic ancestors, as such motifs do in Desert paintings (Spencer and Gillen 1899; Gould 1969). The presence of these paintings suggests that Mulka's Cave may have been the focus of male rituals. If so, the fact that even in daytime it may have been quite dark inside when it was decorated might be significant; especially if those rituals included initiation, which is a form of rebirth, an emergence from darkness into light. Initiation rituals often take place at night, when going into Mulka's Cave would be quite frightening.

We hesitated to question the members of the Mulka's Cave Aboriginal Steering Committee about such a sensitive issue since we are female and not indigenous, but we did establish that they had no objections to us, or female tourists, viewing the artwork. If they had known of any cultural prohibition about women going into Mulka's Cave we are sure they would have told us. On the other hand, so much traditional knowledge was lost in the mid-nineteenth century that people may no longer know about such cultural prohibitions. There is also the possibility that the paintings were not made by the people of the south-west, who now call themselves Noongar, but by men from the Western Desert. In which case, their cultural prohibitions might not be known to or recognised by Noongar people. The members of the steering committee are all Noongar. The Noongar, were and are culturally distinct from all other Aboriginal people; except perhaps the Tasmanians (Bates 1923; Davidson 1939; Tindale 1940, 1974). They marked initiation by scarification. Bates thought the Noongar were the descendants of the first Sahulian colonists, who were culturally swamped by later arrivals everywhere except in Tasmania and the south-west. Bates said that, wherever possible, the later (Desert) people aggressively imposed their initiation rites of circumcision and subincision on those who did neither. Consequently, by the time anthropologists began to study Aboriginal culture in the early twentieth century, the boundary between Noongar and Western Desert people was well defined (Tindale 1940, 1974). Mulka's Cave lies only $75 \mathrm{~km}$ west of this Circumcision Line (Figure 1). Its proximity to the Western Desert may explain why Desert motifs were painted in the cave. They may reflect the westward expansion of Desert customs that Gibbs and Veth (2002) said continued into the early twentieth century. Noongar boys were still being kidnapped and forcibly initiated following Western Desert custom in the 1930s.

We think the size of the handstencils in Mulka's Cave supports our suggestion that the cave may have been used primarily for male rituals. The size of a person's hand reflects their age and gender: adults have larger hands than children, men tend to have larger hands than women. The length of the middle finger or the width across the knuckles is measured as a way of inferring the approximate age and possible gender of the person whose hand was stencilled or printed. Gunn (2006b) argued that infants have a knucklewidth of $<55 \mathrm{~mm}$; children, 55-70 mm; adolescents/women, $70-85 \mathrm{~mm}$; men and large women, $85-95 \mathrm{~mm}$; large men, $>95 \mathrm{~mm}$. If the hands of people of all ages are represented at a given site, the size data should be normally distributed; if not, the data will be skewed.

Gunn and Webb (2000, 2002, 2003, 2006) measured 1,173 handstencils in rock art sites around Cue (Table 2), a small town on the Great Northern Highway, $650 \mathrm{~km}$ north of Perth. Those measurements, converted to age classes, are normally distributed (Figure 10), suggesting that anyone visiting the shelters in which the stencils are located could stencil their hand; although the hands of infants were not often stencilled. The pattern at Mulka's Cave is quite different. Of the 119 hands that could be measured, $40 \%$ of the total recorded, $70 \%$ can be attributed to adolescents and/or women. The absence of very large hands is interesting given that the stencils are supposed to be of Mulka's hands and he was said to be a giant. We suggest that the handstencils in Mulka's Cave more likely belonged to boys than to women and that boys' hands might have been stencilled preferentially during their initiation, as proof of their ties to the site. Whether the cave would have been off-limits to women and children during such ceremonies is not known. As noted above, there are no genderspecific prohibitions connected with the site now.

Most of the individual shelters recorded around Cue housed fewer than 30 handstencils, samples too small to compare with the data from Mulka's Cave,

Table 2 Numbers of handstencils in Mulka's Cave (Gunn 2006a), grouped by age class (Gunn $2006 \mathrm{~b})$, compared with the numbers in the same classes found at Gilla, Poona and Reedy Rockhole (Fig. 11) and more generally around Cue (Gunn and Webb 2000, 2002, 2003, 2006).

\begin{tabular}{lrrrrr}
\hline & infnt & child & adscnt & adult & men \\
\hline Mulka's Cave & 1 & 6 & 83 & 29 & - \\
Cue totals & 26 & 221 & 615 & 228 & 83 \\
Gilla & - & 6 & 25 & 10 & 3 \\
Poona & 1 & 22 & 45 & 16 & 4 \\
Reedy Rockhole & 2 & 18 & 27 & 4 & 1 \\
\hline
\end{tabular}




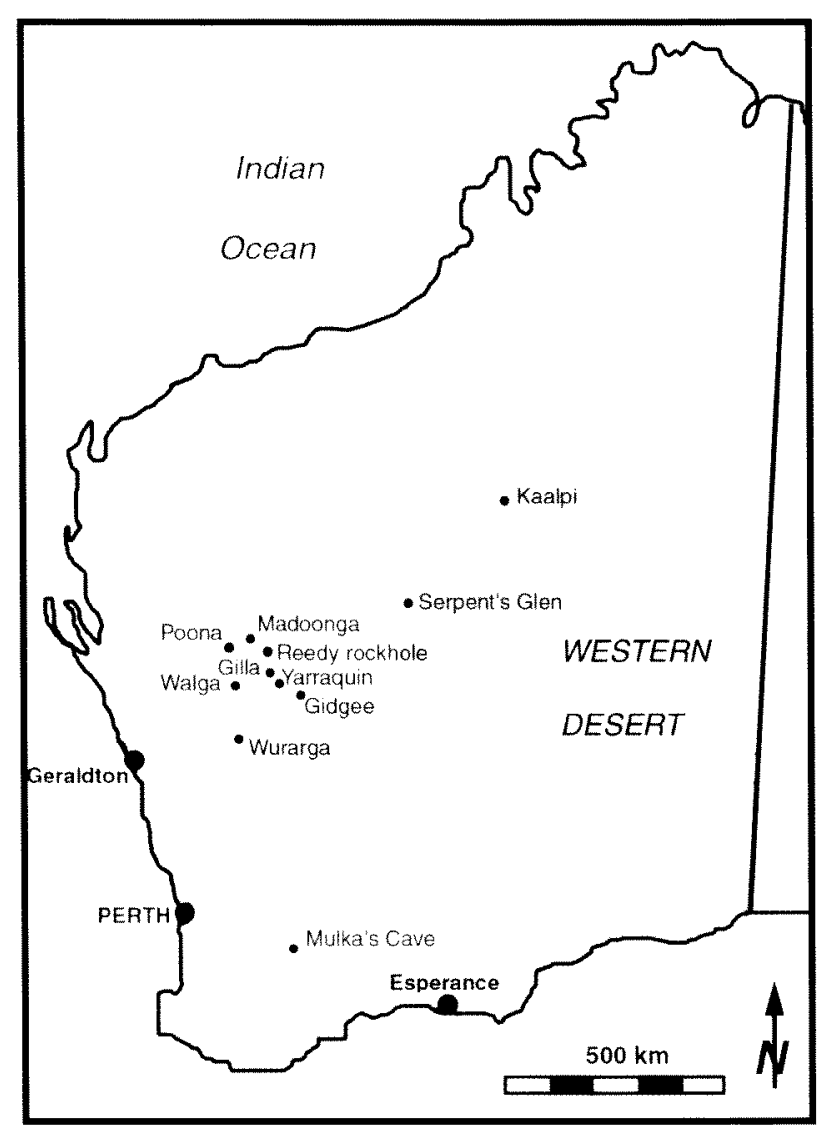

Figure 11 Location of the decorated rockshelters in the southern half of Western Australia referred to in the text.

but Poona (Figure 11) contains 100 hands, 88 of which could be measured (Gunn and Webb 2003: 123-125). This large, open shelter in an elevated stretch of breakaways dominates a small valley. Consequently, the handstencils can be seen from hundreds of metres away. Gunn and Webb (2003: 52) thought this site may have had ceremonial significance when the stencils were made, although this cannot now be verified, because it contains a block of saprolite that has been abraded, possibly during rituals similar to those recorded by Mountford (1976) in the Western Desert. Yet, 25\% of the hands stencilled in Poona belong to children (Table 2). Perhaps they are 'claims to country' (Moore 1977). Certainly, they are highly visible 'public' art.

Two other rockshelters near Cue houses enough handstencils for the pattern of their age/size distribution to be statistically meaningful. Half the 44 measurable handstencils in Gilla can be attributed to adolescents/women, while children's and men's hands are present in approximately equal numbers (Table 2). Similarly, half the 52 measurable handstencils at Reedy Rockhole can be attributed to adolescents/women, while the majority of the remainder can be attributed to children. Both these shelters are situated at the mouth of defiles in which large rockholes have formed. As at Poona, the presence of children's hands may be 'claims to country'. Certainly, the data from Poona, Gilla and Reedy emphasise how unusual the inferred age range of the people whose hands were stencilled in Mulka's Cave is. The predominance of adolescents' hands at Mulka's Cave supports, we believe, our suggestion that the cave was primarily a focus for male ceremonies that perhaps included initiation rituals.

There is some other archaeological evidence that supports our suggestion that Mulka's Cave may have been used differently from other profusely decorated sites in the southern half of Western Australia. Figure 11 shows the location of those sites that have been test excavated and details of whose age and contents are known. The numbers of artefacts discarded at each provide comparative

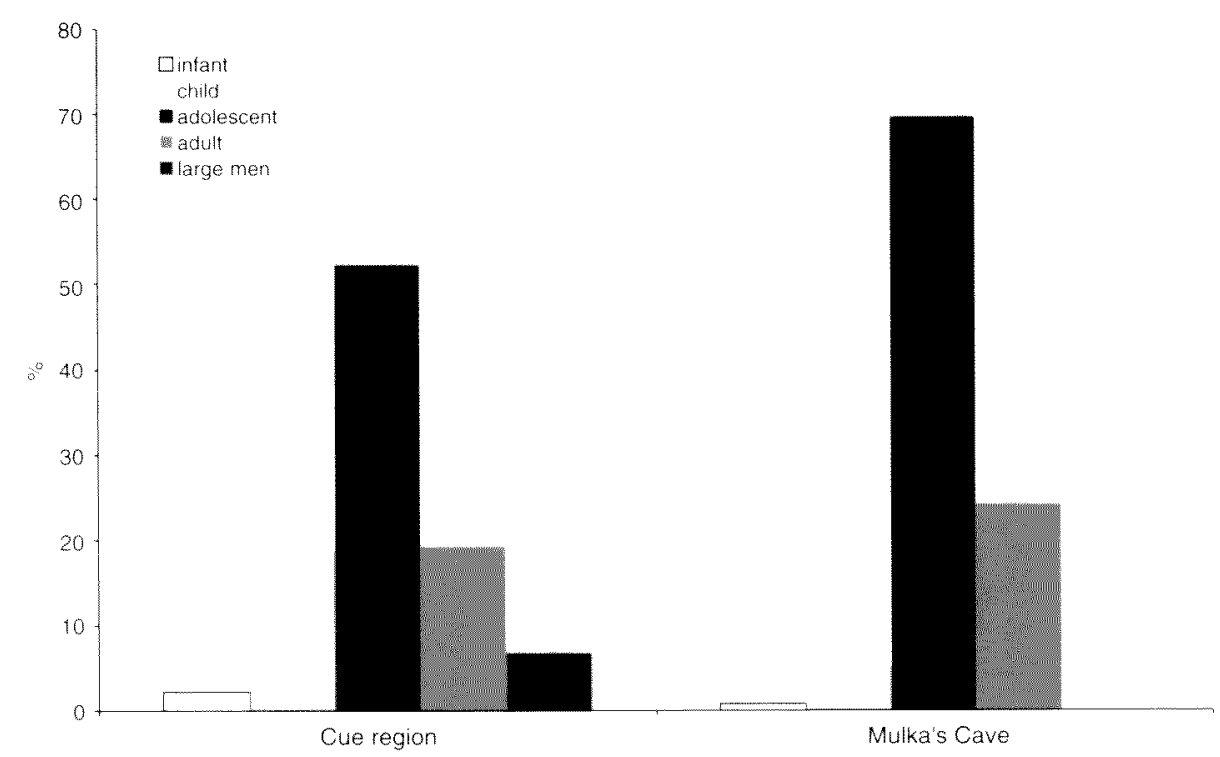

Figure 10 Handstencil sizes grouped by inferred age from sites around Cue, left $(n=1,173)$, and Mulka's Cave, right $(\mathrm{n}=119)$. 
Table 3 The volume of sediment excavated, number of artefacts recovered from levels post-dating $4,000 \mathrm{BP}$ and estimated number of artefacts in a cubic metre of deposit at all the decorated shelters in the southern half of Western Australia for which data are available (Bowdler et al. 1989; O'Connor et al. 1998; Webb and Gunn 1999; Veth et al. 2001; Webb 2008, unpublished data). The artwork in Wurarga is discussed by Hall (1994), that at Gidgee, Gilla, Madoonga and Yarraquin by Gunn and Webb (2000).

\begin{tabular}{lcrr}
\hline site name & volume & number & nos $/ \mathrm{m}^{3}$ \\
\hline Gidgee & $0.5 \times 0.5 \times 0.3 \mathrm{~m}$ & 1,088 & 14,507 \\
Gilla & $0.5 \times 0.5 \times 0.3 \mathrm{~m}$ & 282 & 3,760 \\
Kaalpi & $2.0 \times 1.0 \times 0.4 \mathrm{~m}$ & 841 & 1,051 \\
Madoonga & $1.0 \times 1.0 \times 0.4 \mathrm{~m}$ & 223 & 558 \\
Mulka's Cave & $1.0 \times 1.0 \times 0.6 \mathrm{~m}$ & 280 & 467 \\
Serpent's Glen & $1.0 \times 1.0 \times 1.0 \mathrm{~m}$ & $>1,731$ & $>1,731$ \\
Walga Rock V14 & $1.0 \times 1.0 \times 1.0 \mathrm{~m}$ & 1,507 & 1,507 \\
Walga Rock V15 & $1.0 \times 1.0 \times 1.0 \mathrm{~m}$ & 1,944 & 1,944 \\
Walga Rock W14 & $1.0 \times 1.0 \times 1.0 \mathrm{~m}$ & 1,632 & 1,632 \\
Walga Rock W15 & $1.0 \times 1.0 \times 1.0 \mathrm{~m}$ & 1,714 & 1,714 \\
Wurarga & $1.0 \times 1.0 \times 0.6 \mathrm{~m}$ & 2,678 & 4,463 \\
Yarraquin & $0.5 \times 0.5 \times 0.3 \mathrm{~m}$ & 656 & 8,747 \\
\hline
\end{tabular}

data from which to assess whether the paucity of artefacts found at Mulka's Cave is behaviourally significant. Although each of the sites in Table 3 was in use over a period of different length, the artefacts were all deposited in the last 4,000 years and most are made from quartz. The data in Table 3 suggest that the way Aboriginal people used Mulka's Cave was different from the way they used all the other shelters, except perhaps Madoonga. There is no water collection point near Madoonga. It appears to have been visited mainly to exploit a vein of quartz in the back wall (Webb, unpublished data). Very few artefacts were deposited at either site, supporting the suggestion made by Bowdler et al. (1989) that Mulka's Cave was visited infrequently.

The disparity between the number of artefacts discarded at Walga Rock, one of the most profusely decorated sites in Australia, and those recovered from Mulka's Cave is noteworthy because Walga is known to have been a site of considerable regional significance, although no ceremonies have been held there since the Second World War (Gunn et al. 1997). An unusually high number of 'formal tools' was recovered from Walga (Bordes et al. 1983; Webb and Gunn 1999). Webb suggested this aspect of the assemblage might relate to the site's ceremonial functions. If that suggestion is correct and Mulka's Cave was principally a ceremonial site, then the fact that both we and Bowdler et al. (1989: 24) found very few 'formal tools' there requires further study. We are currently investigating this aspect of the artefacts found within and immediately without the cave and comparing that assemblage with the artefacts found beside the ephemeral creek.

\section{CONCLUSION}

It is ironic that this reconsideration of how Mulka's Cave may have been used in the past only became possible because the site was deteriorating due to over-visitation by tourists. Like Bowdler et al. (1989), we think the cave was rarely visited. We think it was primarily a focus for ceremonies that perhaps included initiation rituals. Gunn (2006a) thought the cave was used as a shelter from inclement weather, but that occupation and ceremonies occurred outside the present entrance; whereas, we think that ceremonies were held in the cave, while occupation occurred by the ephemeral creek; the only place where we have found charcoal. Reconsideration of other aspects of how Aboriginal people used Mulka's Cave and its environs must await the results of the artefact analysis and assessment of the age of the charcoal samples recently submitted for dating.

\section{ACKNOWLEDGEMENTS}

This study would not have been possible without the support of the Mulka's Cave Aboriginal Steering Committee. REW monitored installation of the walkway. AMR researched the rate of erosion and is analysing the archaeological material recovered from the walkway postholes and additional test excavations as an MA by thesis at Edith Cowan University. Her interest in the cave was sparked by helping R.G. Gunn to record the artwork in detail in 2004. He is thanked for permitting us to reproduce some of the drawings he made at that time. We also thank Brian Blurton (DIA Midland), Vicki and Robert Reynolds (DIA Albany) and Jodee Smith for assistance in the field in 2006. Jill and Greg Dwyer, Rolf Meeking, Jane Mouritz and Erin Stringer are thanked for assistance in Hyden. The published version of this paper benefited from critical review by Val Attenbrow and Peter Randolph and editorial comment by Mark Harvey.

\section{REFERENCES}

Bates, D.W. (1923). Tribus du sud-ouest de l'Australie. Revue d'Ethnographie 15: 225-240.

Bayly, I.A.E. (1999). Review of how indigenous people managed for water in desert regions of Australia. Journal of the Royal Society of Western Australia 82: $17-25$.

Bignell, M. (1981). A place to meet: a history of the Shire of Katanning, Western Australia. University of Western Australia Press, Perth. 
Bindon, P.R. (1997). Aboriginal people and granite domes. Journal of the Royal Society of Western Australia 80: 173-179.

Bordes, F., Dortch, C.E., Thibault, C., Raynal, J-P. and Bindon, P. (1983). Walga Rock and Billibilong Spring. two archaeological sequences from the Murchison Basin, Western Australia. Australian Archaeology 17: $1-26$.

Bowdler, S., Harris, J., Murphy, A., Naton, G. and Pocock, C. (1989). Test excavation at Mulka's Cave (Bate's Cave) near Hyden, Western Australia. Unpublished report to the Department of Aboriginal Sites, Western Australian Museum, Perth.

Clarke, J. (1976). Graffiti removal, Bate's Cave, Hyden, Western Australia. Unpublished report to the Department of Aboriginal Sites, Western Australian Museum, Perth

Davidson, D.S. (1939). The relation of Tasmanian and Australian cultures. Publications of the Philadelphia Anthropological Society 1: 47-62.

Davidson, D.S. (1952). Notes on the pictographs and petroglyphs of Western Australia and a discussion of their affinities and appearances elsewhere in the continent. Proceedings of the American Philosophical Society 96: 76-117.

Day, R.B. (1951). The Humps beyond Hyden. The West Australian, 27 January 1951.

Gibbs, M. and Veth, P.M. (2002). Ritual engines and the archaeology of territorial ascendancy. Tempus $7: 11-$ 19.

Gould, R.A. (1969). Yiwara: foragers of the Australian desert. Charles Scribner's Sons, New York.

Green, N.J. (1981). Aborigines and white settlers in the nineteenth century. In C. T. Stannage (ed.) A New History of Western Australia, pp. 72-123. University of Western Australia Press, Perth.

Gunn, R.G. (2004). Mulka's Cave Aboriginal rock art site: an archaeological recording. Unpublished report to the Department of Indigenous Affairs, Perth.

Gunn, R.G. (2006a). Mulka's Cave Aboriginal rock art site: its context and content. Records of the Western Australian Museum 23: 19-41.

Gunn, R.G. (2006b). Hand sizes in rock art: interpreting the measurements of hand stencils and prints. Rock Art Research 23: 97-112.

Gunn, R.G. and Webb, R.E. (2000). Rock art of the Cue region, Western Australia. Unpublished report to the Australian Institute of Aboriginal and Torres Strait Islander Studies, Canberra, and Thoo Thoo Warninha Aboriginal Corporation, Cue.

Gunn, R.G. and Webb, R.E. (2002). Art and Archaeology of part of the Wutha native title claim, east of Cue, W.A. Unpublished report to the Australian Institute of Aboriginal and Torres Strait Islander Studies, Canberra, Thoo Thoo Warninha Aboriginal Corporation, Cue, and the Wutha native title claimants.

Gunn, R.G. and Webb, R.E. (2003). Art and Archaeology on Coodardy, Austin Downs and Noondie pastoral leases, west of Cue, W.A. Unpublished report to the Australian Institute of Aboriginal and Torres Strait
Islander Studies, Canberra, and Thoo Thoo Warninha Aboriginal Corporation, Cue.

Gunn, R.G. and Webb, R.E. (2006). Art and Archaeology on Nallan and Cogla Downs pastoral leases, northeast of Cue, W.A. Unpublished report to the Australian Institute of Aboriginal and Torres Strait Islander Studies, Canberra, Thoo Thoo Warninha Aboriginal Corporation, Cue and the Goldfields Land and Sea Council, Kalgoorlie.

Gunn, R.G., Webb, R.E. and Marmion, D.E. (1997). Walga Rock: a Wajarri rock art and Dreaming site. An unpublished National Estate Grants Program report to Thoo Thoo Wandi Aboriginal Corporation, Cue, the Yamaji Language Centre, Geraldton, and the Australian Heritage Commission, Canberra.

Hall, N.K. (1994). Rock art recording and protection project, mid-West region, WA. Unpublished report to the Department of Aboriginal Sites, Western Australian Museum, Perth, and the Australian Institute of Aboriginal and Torres Strait Islander Studies, Canberra.

Hallam, S.J. (1975). Fire and hearth: a study of European usage and European usurpation in Southwestern Australia. Australian Institute of Aboriginal Studies, Canberra.

Haydock, P. and Rodda, J. (1986). A survey of rock art conservation in the Murchison/Wheatbelt area of WA: a study of past treatments and new methods of measurement and site management. Unpublished report to the Department of Aboriginal Sites, Western Australian Museum, Perth.

Holland, J. (1936). The story of Holland's Track cut from Broomehill to Coolgardie in 1893. MS 522A, Western Australian State (Battye) Library, Perth.

Meggitt, M.J. (1962). Desert People. Angus and Robertson, Sydney.

Moore, D.R. (1977). The handstencil as signal. In P. J. Ucko (ed.) Form in indigenous art, pp. 318-324. Australian Institute of Aboriginal Studies, Canberra.

Mountford, C.P. (1976). Nomads of the Australian desert. Rigby, Adelaide.

Mulvaney, D.J. and Kamminga, J. (1999). Prehistory of Australia. Allen \& Unwin, St Leonards, NSW.

O'Connor, S., Veth, P.M. and Campbell, C. (1998). Serpent's Glen: report on the first Pleistocene-aged occupation sequence from the Western Desert. Australian Archaeology 46: 12-22.

Randolph, P. (1973). Bates Cave, Hyden. Unpublished report to the Department of Aboriginal Sites, Western Australian Museum, Perth.

Rodda, J. (1989). Mulka's Cave site management project. Unpublished report to the Western Australian Heritage Commission and the Department of Aboriginal Sites, Western Australian Museum, Perth.

Roe, J.S. (1852). Report of an expedition under the Surveyor-General, Mr J. S. Roe, to the south-eastward of Perth, in Western Australia, between the months of September, 1848, and February, 1849, to the Hon. the Colonial Secretary. Journal of the Royal Geographical Society 22: 1-57.

Rossi, A.M. and Webb, R.E. (2008). The erosive effect of tourism at an Aboriginal rock art site on the western 
edge of the arid zone in south-western Australia. Antiquity 82 (available at http://www.antiquity.ac.uk/ ProjGall/rossi/index.html)

Rossi, A.M. and Webb, R.E. (in press). The consequences of allowing unfettered tourist access at an Aboriginal site in a fragile environment: the erosive effect of trampling. Conservation and Management of Archaeological Sites.

Serventy, V. (1952). Cave paintings near York and Hyden. The Western Australian Naturalist 13: 121-130.

Spencer, B. and Gillen, F.J. (1899). The Native Tribes of Central Australia. Macmillan and Co. Ltd, London.

Theunissen, R., Balme, J. and Beck, W. (1998). Headroom and human trampling: cave ceilingheight determines the spatial patterning of stone artefacts at Petzkes Cave, northern New South Wales. Antiquity 72: 80-89.

Tindale, N.B. (1940). Distribution of Australian Aboriginal tribes: a field survey. Transactions of the Royal Society of South Australia 64: 140-231.

Tindale, N.B. (1974). Aboriginal tribes of Australia: their terrain, environmental controls, distribution, limits and proper names. Los Angeles/Berkeley: University of California Press.

Twidale, C.R. and Bourne, J.A. (2004). Notes on the geomorphology of The Humps, near Hyden, Western Australia. Journal of the Royal Society of Western Australia 87: 123-133.
Veth, P.M., Smith, M.A. and Haley, M. (2001). Kaalpi: the archaeology of an outlying range in the dunefields of the Western Desert. Australian Archaeology 52: 9-17.

Webb, R.E. (2006). Preliminary report on archaeological monitoring undertaken in May 2006 at Mulka's Cave, near Hyden, under Section 18 of the Western Australian Aboriginal Heritage Act (1972, revised 2004). Unpublished report to the Water Corporation, Albany, the Department of Indigenous Affairs, Perth, and the Hyden-Karlgarin and District Landcare Group, Hyden.

Webb, R.E. (2008). Results of test excavating three decorated rockshelters east of Cue, WA. Unpublished report to the Australian Institute of Aboriginal and Torres Strait Islander Studies, Canberra, Thoo Thoo Warninha Aboriginal Corporation, Cue, and the Goldfields Land and Sea Council, Kalgoorlie.

Webb, R.E. and Gunn, R.G. (1999). Walga Rock, part ii: preliminary artefact analysis and detailed art recording. Second report to the Yamaji Language Centre, Geraldton, and the Australian Heritage Commission, Canberra.

Webb, R.E. and Gunn, R.G. (2004). Re-recording culturally significant Aboriginal sites in southwestern Australia as a guide to Noongar usage of the region in the past. Rock Art Research 21: 93-97.

Manuscript received 3 April 2007; accepted 13 November 2007. 


\section{Guide to Authors}

\section{Records of the Westem Alustralian Museam}

\begin{abstract}
Subject Matter
Original research. reviews and observations in all branches of natural science and human studies will be comsidered for publication. However emphasis is placed on studics pertatining 10 Western Australiat and neighboring regions. Longer papers will be considered for publication as Supplements to the Records of the Western Australian Musemm. Such publications may attract chatges to the atuthors to off set the costs of printing - authors should consult the editors before submiting large manuscripts. Short communications should not normally exceed three typed pages and this category of paper is intended to accommodate observations, results or new reconds of significance. All material must be original and not have been published clsewhere.
\end{abstract}

\section{Presentation}

Authors are advised to follow the layout and style in the most recent issue of the Records of the Westerm Australian Musem including headings. tables, illustrations and references. When in doubt, use a simple format that is easily edited. Please provide line numbers throughout the MS (e.g., in Word go to File Page Setup Layout (tab) Line Numbers (button), add line numbers and click on "continuous" numbering).

The title should be concise, informative and contain key words necessary for retrieval by modem searching techniques. An abridged title (not exceeding 50 character spaces) should be included for use as a running head.

An abstract must be given in full length papers but not shont communications. summarizing the scope of the work and principal findings. It should normally not exceed $2 \%$ of the paper and be suitable for reprinting in reference periodicals. At the end of the abstract, provide several keywords not already included in the title.

The International System of units should be used. Spelling should follow the Concise Oxford Dictionary. Numbers should be spelled out from one to nine in descriptive text: figures used for lo or more. For associated groups, figures should be used consistently te.g. "5 to 10 ". not "five to $10 "$ ).

Systematic papers must conform with the International Codes of Botanical and Zoological Nomenclature and. as far as posible, with their recommendations.

Synonymies should be given in the short form (taxon. author. date patere and the full reference cited at the end of the paper. All citations. including those associated with scientific names in taxonomic works, must be included in the references.

\section{Manuscripts}

Mantiscripts should be submitted electronically as PDF's or Word tiles to the editors (listed below). For manuscripts with large imatge likes submission of a CD is acceptable. Manuseript mus be 1.5 or double-spaced throughout and mareim at lean $25 \mathrm{~mm}$ wide. On separate pages include tables uplus headings) and tigure legends. Tables hould be numbered consecutivel, hare headinge which make them understandable withat reterence whe kest. yell out generic names and be

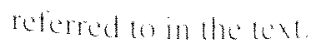

\section{Figures}

Lower resolution images can be inserted into a PDF or Word document for review. Upon acceptance. high resolution to$10 \mathrm{Mb}$ ) images in TIFF or JPEG format can be e-mailed or burned to CD and posted to the editors. We prefer TIFF files for figures. For Adobe Illustrator and Sigmaplot. save in eps (encapsulated postscript) format: for PowerPoint, save in . wmt (windows metafile format): for Excel. save as Excel 97 worksheet (must contain spreadsheet and embedded chart): and for CorelDraw, save as an eps file that may be opened by Adobe Illustrator.

Scanned photographs should be saved as TIFF files. All TIFF tiles should be compatible with Adobe Photoshop. If figures are prepared in a paint program. for black-and-white line art save at 600 dpi as a black-and-white bitmap (not greyscale or colour), and greyscale and colour line art at 300 dpi.

Scale must be indicated on illustrations. Use arrows of other aids to indicate specific features mentioned in the text. All maps. line drawings, photographs and graphs should be numbered in sequence and referred to as "Figure" (no abbreviation) in the text and captions. Each figure should have a brief. fully explanatory caption.

\section{References}

In the body of the text. references should be cited as follows:

McKenzie and colleatues (Mckenzic 1999. 2000). Mckenzie ef al. 2000) found that hat frequencies were highest on full moons, contra previous workers (Smith and Jones 1982: Berman 1988: Zucker et al. 1992).

All references must be cited in the text by author and date and all must be listed alphabetically at the end of the paper. The names of journals are to be given in full. Consult a recent edition of the Records for style. For taxonomic papers, include full references for all taxonomic groups mentioned in the text. In manuscripts dealing with historical subjects references may be cited as foomotes.

\section{Processing}

All manuscripts are reviewed by at least two referees whose reports assist the editors in making their decision whether to accept the paper. The review process usually takes from one to three months, although the review process and typesetting for longer manuscripts and supplements are usually longer.

The senior author is sent one set of page proofs electronically which mus be returned within one week atter receipt.

The senior author will receive 25 free reptints, a PDF and a copy of the entire issue. Additional offprints can be ordered al page proot stage.

\section{Editors}

Manuscripts can be submitted to either Mark Hartes (mark harvey (a museum, waterova: inverkbrate anmats) or Paul Doughty (pauldoughty (emuseum. Wagohau: human

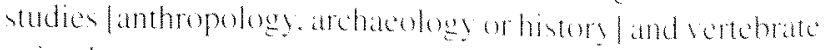
animals). 


\section{Records of the Western Australian Museum Volume 24 Part 32008}

\section{CONTENTS}

Thomas A. Darragh and George W. Kendrick

Silicified Eocene molluscs from the Lower Murchison district,

Southern Carnarvon Basin, Western Australia

Paul Doughty, Paul Oliver and Mark Adams

Systematics of stone geckos in the genus Diplodactylus (Reptilia: Diplodactylidae) from northwestern Australia, with a description of a new species from the Northwest Cape, Western Australia

Ivana Karanovic

Three interesting Cyprididae (Ostracoda) from Western Australia 267

\section{Brian V. Timms}

Further studies on the fairy shrimp genus Branchinella

(Crustacea, Anostraca, Thamnocephalidae) in Western Australia,

with descriptions of new species

\section{R. Esmée Webb and Alana M. Rossi}

How was Mulka's Cave, an Aboriginal rock art site near Hyden, in south-central Western Australia, used by the people who decorated its walls, when the present entrance was much smaller? 